\title{
OPTIMASI SUHU DAN LAMA PENGUKUSAN UNTUK MEMPERPANJANG UMUR SIMPAN GETUK PISANG RAINBOW
}

\author{
${ }^{*}$ FATIMAH ${ }^{1}$, ERFANUR ADLHANI $^{1}$, DWI SANDRI ${ }^{1}$ \\ ${ }^{1}$ Jurusan Teknologi Industri Pertanian, Politeknik Negeri Tanah Laut, Jl. A. Yani, Km. 6, Ds. \\ Panggung, kec. Pelaihari, kab Tanah Laut, Kalimantan Selatan
}

Naskah diterima : 19 September 2016 ; Naskah disetujui : 10 Oktober 2016

\begin{abstract}
ABSTRAK
Getuk merupakan pangan semi basah yang biasanya terbuat dari ubi kayu melalui tahap persiapan bahan, pengukusan, penghancuran atau penumbukan, pencampuran bahan tambahan dan pencetakan atau pembentukan. Getuk pisang rainbow merupakan produk inovasi olahan getuk berbahan baku pisang uli. Produk ini dinamakan getuk rainbow karena memiliki tiga variasi warna sehingga terlihat seperti pelangi. Tujuan penelitian ini adalah untuk memperpanjang umur simpan getuk pisang rainbow dengan melakukan optimasi terhadap suhu dan lama pengukusan getuk. Penelitian ini menggunakan rancangan acak lengkap $(R A L)$ dengan variasi suhu $60^{\circ} \mathrm{C}$, $70^{\circ} \mathrm{C}, 80^{\circ} \mathrm{C}$, dan $90^{\circ} \mathrm{C}$ dan variasi waktu untuk masing-masing suhu pengukusan 15 menit, 30 menit, dan 45 menit. Penentuan umur simpan dilakukan menggunakan metode Extended Storage Studies (ESS) yaitu penentuan tanggal kadaluwarsa dengan jalan menyimpan suatu seri produk pada kondisi normal sehari-hari sambil dilakukan pengamatan terhadap penurunan mutunya hingga mencapai tingkat mutu kadaluwarsa. Hasil menunjukkan bahwa suhu pengukusan terbaik diperoleh pada suhu $80^{\circ} \mathrm{C}$ dengan waktu pengukusan selama 45 menit yang mana getuk pisang rainbow diterima oleh panelis $80 \%$ dengan waktu penyimpanan selama 2 hari, dan berdasarkan hasil pengamatan bakteri, getuk pisang rainbow dapat bertahan selama 2 hari dengan jumlah mikroba yang melewati ambang batas yang diperbolehkan pada hari ke-3.
\end{abstract}

Kata kunci : getuk, getuk pisang rainbow, umur simpan

\section{PENDAHULUAN}

Getuk pisang rainbow merupakan produk inovasi olahan getuk berbahan baku pisang uli. Produk ini dinamakan getuk rainbow karena memiliki tiga variasi warna sehingga terlihat seperti pelangi. Pewarna yang digunakan merupakan pewarna alami dari campuran sari buah naga, daun suji, dan labu kuning. Berdasarkan kajian sebelumnya yang telah dilakukan, produk inovasi ini terbukti dapat meningkatkan nilai ekonomis pisang uli, dimana selama ini pisang uli sebagian besar hanya dimanfaatkan sebagai buah pencuci mulut saja. Pada saat panen, biasanya pisang uli yang melimpah terjual hanya Rp 5.000 per tandannya, sedangkan penjualan getuk pisang rainbow memperoleh keuntungan hingga Rp 1.001.579/bulan (Erna, 2015).

Dikatakan pula oleh Erna (2015), dibalik kelebihan getuk pisang rainbow terdapat pula kekurangannya, yaitu umur simpan yang hanya bertahan selama satu hari pada suhu ruang dan tiga hari apabila disimpan dalam lemari es. Proses pembuatan getuk pisang rainbow yang dilakukan Erna menggunakan metode pengukusan dengan air mendidih di atas kompor selama 30-45 menit tanpa dilakukan pengukuran suhu pengukusan.

*Korespondensi:

Telp. : 085754517638

Email : fatimah@politala.ac.id 
Menurut Herawati (2008), untuk memperpanjang umur simpan produk pangan dapat dilakukan dengan peningkatan mutu awal atau dengan perlakuan selama proses penyimpanan. Peningkatan nilai mutu awal produk dapat dilakukan dengan memilih dan menggunakan bahan baku yang bermutu baik serta proses pengolahan yang benar. Beberapa proses penanganan produk pangan yang dapat menyebabkan terjadinya perubahan mutu adalah perlakuan panas tinggi, pembekuan, pencampuran, serta pemompaan. Hasil penelitian Sukmaningsih dkk. (2005) mengenai masa simpan daging ayam buras setelah dikukus sebelum pemasaran, menunjukkan bahwa perlakuan pengukusan uap panas suhu $80^{\circ} \mathrm{C}$ selama 2 , , dan 6 menit sebelum pemasaran mampu menurunkan jumlah bakteri, sehingga dapat lebih lama disimpan yaitu sampai 8 jam pada suhu ruang.

Berdasarkan hasil-hasil penelitian sebelumnya ini, maka dengan menurunkan suhu dan lama pengukusan ada kemungkinan umur simpan getuk pisang rainbow dapat ditingkatkan. Hasil yang diperoleh nantinya diharapkan dapat menambah nilai ekonomis getuk pisang rainbow. Berdasarkan latar belakang maka dapat dirumuskan permasalahan yaitu apakah optimasi suhu dan lama pengukusan dapat memperpanjang umur simpan getuk pisang rainbow.

\section{METODE PENELITIAN}

\section{Alat dan Bahan Penelitian}

Peralatan yang digunakan dalam pembuatan getuk pisang rainbow adalah kompor, timbangan analitik, panci, cetakan, nampan, baskom, pisau dan sarung tangan plastik. Sedangkan peralatan untuk penentuan umur simpan adalah cawan petri, timbangan analitik, stoples modifikasi, pengepres plastik, oven, desikator, mortar, gelas ukur, pencepit logam.

Bahan yang digunakan dalam pembuatan getuk pisang rainbow adalah pisang uli, tepung terigu, margarin, gula pasir, vanili, buah naga, daun suji dan labu kuning. Sedangkan bahan-bahan pendukung, berupa bahan-bahan kimia yang digunakan untuk penentuan umur simpan adalah kemasan plastik PP, media NA, media NB, dan akuades

Rancangan penelitian yang digunakan adalah rancangan acak lengkap (RAL), dengan perlakuan yaitu variasi suhu pengukusan pada suhu $60^{\circ} \mathrm{C}, 70^{\circ} \mathrm{C}, 80^{\circ} \mathrm{C}$, dan $90^{\circ} \mathrm{C}$ dan variasi waktu untuk masing-masing suhu pengukusan 15 menit, 30 menit, dan 45 menit yang dtunjukkan pada Tabel 1 dengan pengulangan sebanyak 3 kali. Penentuan umur simpan dilakukan menggunakan metode Extended Storage Studies (ESS), yaitu penentuan tanggal kadaluwarsa dengan jalan menyimpan suatu seri produk pada kondisi normal sehari-hari sambil dilakukan pengamatan terhadap penurunan mutunya (usable quality) hingga mencapai tingkat mutu kadaluwarsa.

Tabel 1. Kode Perlakuan Penelitian

\begin{tabular}{cccc}
\hline Suhu $(\mathrm{T})$ & \multicolumn{3}{c}{ Waktu $(\mathrm{W})$} \\
\cline { 2 - 4 } & 15 menit & 30 menit & 45 menit \\
\hline $60^{\circ} \mathrm{C}$ & $\mathrm{T} 6 \mathrm{~W} 1$ & T6W2 & T6W3 \\
$70^{\circ} \mathrm{C}$ & $\mathrm{T} 7 \mathrm{~W} 1$ & T7W2 & T7W3 \\
$80^{\circ} \mathrm{C}$ & $\mathrm{T} 8 \mathrm{~W} 1$ & T8W2 & T8W3 \\
$90^{\circ} \mathrm{C}$ & $\mathrm{T} 9 \mathrm{~W} 1$ & T9W2 & T9W3 \\
\hline
\end{tabular}

\section{Pembuatan Pewarna Alami}

Pewarna yang digunakan untuk membuat getuk pisang rainbow ini adalah pewarna alami. Masing-masing bahan dibersihkan dan dipotong kecil, untuk mendapatkan warna hijau ditimbang 
$75 \mathrm{~g}$ daun suji dan ditambah $200 \mathrm{ml}$ air, untuk mendapatkan warna kuning ditimbang $150 \mathrm{~g}$ labu kuning dan ditambah $100 \mathrm{ml}$ air, dan untuk mendapatkan warna merah ditimbang $150 \mathrm{~g}$ buah naga dan ditambah $100 \mathrm{ml}$ air. Kemudian diblender masing-masing bahan yang sudah ditambah air diambil ekstraknya.

\section{Pembuatan Getuk Pisang Rainbow}

Pada pembuatan getuk pisang rainbow, pertama disiapkan semua bahan dan peralatan yang di perlukan. Setelah semua siap, dikukus $1 \mathrm{~kg}$ pisang uli selama \pm 10 menit, diangkat dan dikupas kulitnya dan dihaluskan. Pisang uli yang sudah dihaluskan ditambahkan $150 \mathrm{~g}$ mentega, $1 \mathrm{~g}$ vanili, $250 \mathrm{~g}$ tepung, $150 \mathrm{~g}$ gula, dan diaduk hingga tercampur rata. Adonan yang sudah tercampur rata dibagi menjadi tiga bagian, masing-masing adonan ditambahkan pewarna alami sesuai dengan keinginan. Setalah itu, dicetak adonan sesuai dengan keinginan, dikukus dengan variasi suhu yaitu $60^{\circ} \mathrm{C}, 70^{\circ} \mathrm{C}, 80^{\circ} \mathrm{C}$ dan $90^{\circ} \mathrm{C}$ dengan variasi waktu untuk masing-masing suhu pengukusan 15 menit, 30 menit, dan 45 menit. Getuk kemudian diangkat dan didinginkan dan selanjutnya dikemas menggunakan plastik jenis polipropilen (PP).

\section{Uji Organoleptik}

Tahap selanjutnya yang dilakukan adalah mengetahui respon organoleptik terhadap getuk pisang rainbow untuk mengetahui pengaruh suhu dan lama pengukusan terhadap lama penyimpanan. Atribut yang akan diuji meliputi warna, aroma dan tekstur. Pada pelaksanaan uji organoleptik, disiapkan getuk pisang rainbow yang akan diuji oleh 5 orang panelis dan panelis diberikan score sheet yang berisi parameter penilaian. Panelis diminta mengisi score sheet yang telah diberikan untuk menilai getuk pisang rainbow. Parameter penilaian yang digunakan dapat dilihat pada Tabel 2.

Tabel 2. Parameter Penilaian

\begin{tabular}{lll}
\hline Warna & Aroma & Tekstur \\
\hline 1 = Pudar & 1 = Tengik & $1=$ Lembek, berlendir \\
2 = Agak pudar & 2 = Agak tengik & $2=$ Agak lembek \\
$3=$ Tajam & 3 = Pisang segar & $3=$ Padat berisi \\
\hline
\end{tabular}

\section{Persiapan Pengamatan Bakteri}

Analisis selanjutnya yang dilakukan adalah melakukan pengamatan bakteri pada getuk pisang rainbow. Untuk pengamatan mikroba menggunakan media NA menggunakan metode pour plate. Pertama-tama disiapkan semua alat dan bahan yang diperlukan. Media NA ditimbang sebanyak $28 \mathrm{~g}$ dan dimasukkan ke dalam erlenmeyer dan ditambahkan aquadest sebanyak $1000 \mathrm{ml}$. Campuran dipanaskan di atas hot plate, diaduk dengan magnetic stirer hingga mendidih atau berubah warna menjadi bening. Kemudian diangkat, dikeluarkan magnetic stirrer, ditutup dengan aluminium foil dan diikat menggunakan karet gelang. Setelah itu disiapkan sepuluh buah tabung reaksi kemudian diisi dengan aquadest sebanyak $9 \mathrm{ml}$ tiap tabung dan ditutup dengan aluminium foil. Setelah semuanya siap, bahan dan alat disterilkan dalam auto clave pada suhu $121^{\circ} \mathrm{C}$ selama 15 menit. Setelah itu, bahan dan alat dikeluarkan setelah suhu auto clave kembali normal pada suhu kamar.

\section{Pengamatan Bakteri Pada Getuk Pisang Rainbow}

Tahap selanjutnya yang dilakukan yaitu pengamatan bakteri pada getuk pisang rainbow, pertama disiapkan dan dibersihkan ruangan (laminar airflow) dengan alkohol. Media yang sudah steril, dicairkan dengan cara dipanaskan diatas hot plate. Ditimbang sampel (getuk pisang rainbow) sebanyak $1 \mathrm{~g}$ dan dimasukkan ke dalam tabung reaksi yang berisi $9 \mathrm{ml}$ aquades steril dan 
dihomogenkan. Setelah homogen, diambil $1 \mathrm{ml}$ dengan mikro pipet dan dimasukkan ke dalam cawan petri yang sudah disterilkan. Setelah itu dituang media NA yang masih hangat sebanyak \pm 10 $\mathrm{ml}$ secara aseptis dan cawan petri ditutup kembali. Kemudian cawan petri diputar menyerupai angka 8 sebanyak 8 kali agar media menyebar rata. Setelah itu cawan petri ditutup dengan plastik (wrapping) dan diinkubasi pada suhu ruang selama \pm 24 jam dengan posisi cawan petri dalam keadaan terbalik. Selanjutnya dilakukan penghitungan jumlah bakteri dengan rumus sebagai berikut,

Angka Lempeng Total (ALT) $=\frac{\text { koloni yang diperoleh }}{\text { faktor pengenceran }} \times 1(\mathrm{CFU} / \mathrm{g})$

\section{Analisis Kadar Air}

Penentuan kadar air dengan metode gravimetri. Dioven cawan porselin selama 15 menit dengan suhu $80^{\circ} \mathrm{C}$ dan dimasukkan ke dalam desikator selama 15 menit. Ditimbang sampel (getuk pisang rainbow) sebanyak $\pm 1 \mathrm{~g}$ dan dioven dengan suhu $80^{\circ} \mathrm{C}$ selama 4 jam. Setelah itu, dilakukan constant weight selama satu jam dengan catatan sampel tidak gosong.

\section{HASIL DAN PEMBAHASAN}

Berdasarkan uji organoleptik yang dilakukan sebanyak tiga kali ulangan. Uji organoleptik pada getuk pisang rainbow (Gambar 1) dilakukan untuk mengetahui pengaruh suhu dan waktu pengukusan terhadap penerimaan panelis yang dilakukan setiap hari selama penyimpanan 3 hari sampai semua panelis menyatakan menolak terhadap getuk pisang rainbow. Parameter yang digunakan pada uji oragnoleptik meliputi warna, aroma, dan tekstur. Hasil rata-rata dan penerimaan panelis terhadap produk getuk pisang rainbow yang dilakukan dapat dilihat pada Tabel 3.

Tabel 3. Hasil Uji Organoleptik Pengaruh Perlakuan Terhadap Getuk Pisang Rainbow

\begin{tabular}{|c|c|c|c|c|c|c|c|c|c|c|c|c|c|}
\hline \multirow{3}{*}{ Perlakuan } & \multicolumn{12}{|c|}{ Parameter pengamatan, lama penyimpanan (hari) } & \multirow{3}{*}{$\begin{array}{c}\text { Penerimaan panelis } \\
(\%)\end{array}$} \\
\hline & \multicolumn{4}{|c|}{ Warna } & \multicolumn{4}{|c|}{ Aroma } & \multicolumn{4}{|c|}{ Tekstur } & \\
\hline & 0 & 1 & 2 & 3 & 0 & 1 & 2 & 3 & 0 & 1 & 2 & 3 & \\
\hline T6W1 & 1.8 & 1.6 & 1.4 & 1.2 & 3 & 3 & 2 & 2 & 1.2 & 1.2 & 1 & 1 & $100 \%$ menolak pada $\mathrm{h}-0$ \\
\hline T6W2 & 2.2 & 2 & 1.6 & 1.6 & 3 & 3 & 2 & 2 & 1.8 & 1.8 & 1.2 & 1.2 & $100 \%$ menolak pada $\mathrm{h}-1$ \\
\hline T6W3 & 3 & 2 & 1.8 & 1.6 & 3 & 3 & 3 & 2 & 2.4 & 2 & 2 & 1.6 & $60 \%$ menolak pada h- 1 \\
\hline T7W1 & 1.8 & 1.6 & 1.4 & 1.2 & 3 & 3 & 2 & 2 & 2 & 2 & 1.8 & 1.8 & $100 \%$ menolak pada h-2 \\
\hline T7W2 & 2.2 & 2 & 1.6 & 1.6 & 3 & 3 & 3 & 3 & 2.4 & 2 & 2 & 2 & $100 \%$ menolak pada h-2 \\
\hline T7W3 & 2.8 & 2.8 & 2 & 2 & 3 & 3 & 3 & 3 & 2.6 & 2.2 & 2 & 2 & $100 \%$ menolak pada $\mathrm{h}-2$ \\
\hline T8W1 & 2.8 & 2.6 & 2 & 2 & 3 & 3 & 3 & 3 & 2.6 & 2 & 1.8 & 1.6 & $80 \%$ menolak pada h- 2 \\
\hline T8W2 & 3 & 2.8 & 2 & 2 & 3 & 3 & 3 & 3 & 2.8 & 2.2 & 2 & 1.8 & $40 \%$ menolak pada h-2 \\
\hline T8W3 & 3 & 2.8 & 2 & 2 & 3 & 3 & 3 & 3 & 3 & 2.6 & 2 & 2 & $20 \%$ menolak pada h-2 \\
\hline T9W1 & 2.8 & 2.6 & 2 & 2 & 3 & 3 & 3 & 3 & 2 & 2 & 1.8 & 1.4 & $80 \%$ menolak pada h-2 \\
\hline T9W2 & 3 & 2.8 & 2 & 2 & 3 & 3 & 3 & 3 & 2.6 & 2.4 & 2 & 2 & $60 \%$ menolak pada h-2 \\
\hline T9W3 & 3 & 2.8 & 2 & 2 & 3 & 3 & 3 & 3 & 2.8 & 2.8 & 2.4 & 2 & $80 \%$ menolak pada h-2 \\
\hline
\end{tabular}




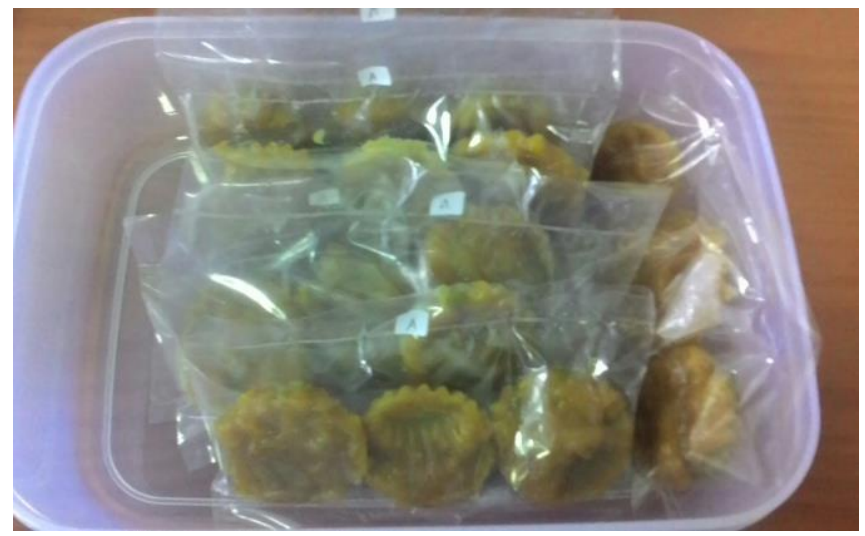

Gambar 1. Getuk pisang rainbow

Hasil uji organoleptik menunjukkan bahwa penerimaan panelis untuk perlakuan pada pengukusan dengan suhu $60{ }^{\circ} \mathrm{C}$ dan $70{ }^{\circ} \mathrm{C}$ kurang disukai panelis, tetapi untuk perlakuan pengukusan pada suhu $80^{\circ} \mathrm{C}$ dan $90^{\circ} \mathrm{C}$ lebih disukai panelis. Semakin tinggi suhu dan semakin lama pengukusan yaitu pada suhu $90^{\circ} \mathrm{C}$ dan waktu 45 menit menjadikan tekstur produk kurang menarik dengan jumlah penolakan mencapai $80 \%$ ketika produk telah disimpan selama 2 hari. Sedangkan pada pengukusan dengan suhu $80^{\circ} \mathrm{C}$ dan waktu selama 45 menit merupakan produk yang lebih disukai panelis dengan jumlah penolakan sebanyak $20 \%$ pada produk yang telah disimpan selama 2 hari. Semakin tinggi suhu dan lama pengukusan menyebabkan tekstur yang kurang disukai panelis yang mana tekstur getuk menjadi agak lembek. Hal ini disebabkan karena getuk meyerap air pengukusan lebih banyak dibandingkan perlakuan dengan suhu yang lebih rendah dan waktu yang lebih singkat seperti yang terlihat pada data hasil analisis kadar air pada Tabel 5.

\section{Pengamatan Jumlah Bakteri}

Pertumbuhan mikroba pada produk pangan dipengaruhi oleh faktor intrinsik dan ekstrinsik. Faktor intrinsik mencakup keasaman $(\mathrm{pH})$, aktivitas air (aw), kandungan nutrisi, dan struktur biologis. Faktor ekstrinsik meliputi suhu penyimpanan, kelembapan relatif, serta jenis dan jumlah gas pada lingkungan (Arpah 2001). Berikut adalah hasil pengamatan jumlah mikroba yang dilakukan selama 3 hari penyimpanan.

Tabel 4. Hasil Pengamatan Jumlah Bakteri

\begin{tabular}{ccccc}
\hline \multirow{2}{*}{ Perlakuan } & \multicolumn{3}{c}{ Jumlah bakteri $\left(\mathrm{x} 10^{2} \mathrm{CFU} / \mathrm{g}\right)$ dengan lama penyimpanan (hari) } \\
\cline { 2 - 5 } & 0 & 1 & 2 & 3 \\
\hline T6W1 & 59 & 183 & 249 & 228 \\
T6W2 & 61 & 193 & 118 & 168 \\
T6W3 & 71 & 176 & 165 & 238 \\
T7W1 & 85 & 207 & 119 & 305 \\
T7W2 & 65 & 137 & 128 & 148 \\
T7W3 & 60 & 133 & 152 & 226 \\
T8W1 & 91 & 104 & 220 & 324 \\
T8W2 & 76 & 97 & 203 & 238 \\
T8W3 & 84 & 84 & 170 & 293 \\
T9W1 & 85 & 63 & 220 & 314 \\
T9W2 & 71 & 89 & 116 & 227 \\
T9W3 & 79 & 67 & 157 & 338 \\
\hline
\end{tabular}


Berdasarkan data diatas, menunjukkan bahwa suhu pengukusan dan waktu pengukusan berpengaruh terhadap jumlah mikroba yang dihasilkan. Semakin tinggi suhu dan lama pengukusan, mengakibatkan jumlah mikroba cenderung berkurang. Ini dikarenakan mikroba sukar tumbuh pada suhu yang lebih tinggi. Pengukusan yang dilakukan pada suhu $60^{\circ} \mathrm{C}$ dan $70^{\circ} \mathrm{C}$ pada semua suhu pengukusan serta pada suhu $80^{\circ} \mathrm{C}$ pada suhu pengukusan 15 menit, jumlah mikroba yang dihasilkan lebih dari $1 \times 10^{4} \mathrm{CFU} / \mathrm{g}$ untuk getuk yang disimpan selama 1 hari, artinya getuk tidak bisa dikonsumsi lagi pada hari ke-2. Batas maksimum cemaran mikroba berdasarkan BPOM (2009) jenis makanan basah olahan adalah ALT $\left(30{ }^{\circ} \mathrm{C}\right.$ selama $\left.72 \mathrm{jam}\right) 1 \times 10^{4} \mathrm{koloni} / \mathrm{g}$ atau $\mathrm{ml}$, APM Koliform kurang dari 3/g atau $/ \mathrm{ml}$, Salmonella sp negatif $/ 25 \mathrm{~g}$ atau negatif $/ 25 \mathrm{ml}$, dan Staphylococcus aureus negatif/g atau negatif/ml. Ini berarti jumlah mikroba yang dihasilkan telah melewati ambang batas yang diperbolehkan oleh BPOM. Sedangkan pengukusan yang dilakukan pada suhu $80^{\circ} \mathrm{C}$ dengan lama 30 dan 45 menit serta pengukusan pada suhu $90^{\circ} \mathrm{C}$, jumlah mikroba yang dihasilkan melewati ambang batas yang diperbolehkan untuk getuk yang disimpan selama 2 hari atau pada hari ke-3 getuk sudah tidak bisa dikonsumsi lagi.

Karlah, dkk (2014) melaporkan, tingginya nilai ALT melebihi standar yang diperbolehkan pada produk saus tomat jajanan bakso tusuk yang diolah sendiri oleh pedagang tidak higenis, mulai dari peralatan masak yang kotor, air yang digunakan untuk pencucian bahan, dan air yang dicampurkan ke dalam saus tomat telah tercemar. Dibandingkan produk pisang rainbow pada hari pertama penyimpanan yang masih memenuhi standar yang diperbolehkan, tetapi terjadi peningkatan jumlah mikroorganisme yang tumbuh selama masa penyimpanan dapat diakibatkan karena adanya kenaikan kadar air pada produk. Kenaikan kadar air akan meningkatkan aktivitas air (aw) produk. Pada nilai aktivitas air (aw) yang cocok, mikroorganisme dapat tumbuh dan berkembang biak. Hal ini sesuai dengan hasil pengamatan bakteri yang dilakukan pada getuk pisang rainbow (Tabel 4), diketahui jumlah total bakteri yang terdapat pada getuk pisang rainbow mengalami peningkatan selama masa penyimpanan.

\section{Kadar Air Getuk}

Kandungan air dalam pangan sangat mempengaruhi tingkat stabilitas atau keawetan pangan. Semakin tinggi kadar air pangan pada umumnya semakin mudah pangan tersebut rusak, baik karena kerusakan mikrobiologis maupun reaksi kimia. Peningkatan kandungan air dalam bahan pangan yang diolah dapat menjadi indikasi penurunan mutu. Peningkatan kadar air melalui penyerapan uap air dari lingkungan menyebabkan produk pangan dapat menurun mutunya. Penurunan mutu tersebut dapat diartikan bahwa produk pangan tersebut mencapai batas umur simpannnya, karena sudah melewati batas kritis kadar airnya (Syarif dan Halid, 1993).

Tabel 5. Hasil Analisis Kadar Air

\begin{tabular}{ccccc}
\hline \multirow{2}{*}{ Perlakuan } & \multicolumn{4}{c}{ Kadar air (\%) dengan lama penyimpanan (hari) } \\
\cline { 2 - 5 } & 0 & 1 & 2 & 3 \\
\hline T6W1 & 33,9 & 34,4 & 36,5 & 37,2 \\
T6W2 & 35,3 & 34,9 & 34,1 & 32,7 \\
T6W3 & 33,7 & 33,4 & 32,7 & 29,3 \\
T7W1 & 38,4 & 37,4 & 38,9 & 37,2 \\
T7W2 & 37,5 & 38,1 & 38,5 & 37,0 \\
T7W3 & 36.4 & 34.5 & 37.0 & 37.0 \\
\hline
\end{tabular}




\begin{tabular}{ccccc}
\hline \multirow{2}{*}{ Perlakuan } & \multicolumn{5}{c}{ Kadar air (\%) dengan lama penyimpanan (hari) } \\
\cline { 2 - 5 } & 0 & 1 & 2 & 3 \\
\hline T8W1 & 38.9 & 39.8 & 40.5 & 41.8 \\
T8W2 & 40.5 & 41.4 & 41.5 & 41.8 \\
T8W3 & 41.1 & 42.6 & 41.6 & 41.8 \\
T9W1 & 40.3 & 41.3 & 41.6 & 43.4 \\
T9W2 & 40.3 & 41.3 & 41.6 & 43.4 \\
T9W3 & 42.7 & 43.1 & 43.2 & 43.5 \\
\hline
\end{tabular}

Perubahan kadar air dipengaruhi oleh suhu dan kelembaban lingkungan selama penyimpanan. Suhu dan kelembaban ruang penyimpanan yang berubah-ubah akan mempengaruhi kadar air yang ada pada getuk pisang rainbow. Kandungan air bahan senantiasa berubah yang dipengaruhi oleh jenis bahan, suhu, dan kelembaban, sehingga bahan menjadi lembab atau kadar air bahan menjadi tinggi.

\section{KESIMPULAN}

1. Getuk pisang rainbow diterima oleh panelis $80 \%$ dengan waktu penyimpanan selama 2 hari, pada perlakuan suhu $80^{\circ} \mathrm{C}$ dan waktu pengukusan selama 45 menit

2. Suhu pengukusan terbaik diperoleh pada suhu $80^{\circ} \mathrm{C}$ dan waktu pengukusan selama 45 menit

3. Getuk pisang rainbow memiliki umur simpan selama 2 hari berdasarkan penerimaan panelis dan pengamatan jumlah mikroba.

\section{DAFTAR PUSTAKA}

Erna, R.W. 2015. Pembuatan Getuk Pisang Rainbow untuk Meningkatkan Nilai Ekonomis Pisang Uli. Skripsi. Program Studi Teknologi Industri Pertanian, Politeknik Negeri Tanah Laut, Pelaihari, Kalimantan Selatan.

Herawati, H. 2008. Penentuan Umur Simpan pada Produk Pangan. Jurnal Litbang Pertanian 27(4).

Karlah, L. R., Mansauda, Fatimawali, Kojong, N. 2014. Analisis Cemaran Bakteri Coliform Pada Saus Tomat Jajanan Bakso Tusuk Yang Beredar Di Manado. Jurnal Ilmiah Farmasi UNSRAT. Vol 3 No 2.

Sukmaningsih, T., Joko, dan Hantoro, A. 2005. Masa Simpan Daging Ayam Buras setelah Dikukus sebelum Pemasaran. Abstrak. Laporan Penelitian Bidang Ilmu Kimia, PDII-LIPI.

Syarif, R. dan Halid. 1993. Teknologi Penyimpanan Pangan. Pusat Studi Antar Universitas IPB. Bogor. 